Article

\title{
Joining of Metal to Ceramic Plate Using Super-Spread Wetting
}

\author{
Jaebong Yeon ${ }^{1, *}$, Michiru Yamamoto ${ }^{1}$, Peiyuan $\mathrm{Ni}^{2}$, Masashi Nakamoto ${ }^{1}$ and Toshihiro Tanaka $^{1}$ \\ 1 Division of Materials and Manufacturing Science, Graduate School of Engineering, Osaka University, \\ 2-1 Yamadaoka, Suita, Osaka 565-0871, Japan; michiru2216@i.softbank.jp (M.Y.); \\ nakamoto@mat.eng.osaka-u.ac.jp (M.N.); tanaka@mat.eng.osaka-u.ac.jp (T.T.) \\ 2 School of Metallurgy, Northeastern University, Shenyang 110819, China; nipeiyuan@smm.neu.edu.cn \\ * Correspondence: Yeon.jaebong@mat.eng.osaka-u.ac.jp; Tel.: +81-6-6879-7468
}

Received: 9 September 2020; Accepted: 10 October 2020; Published: 15 October 2020

check for updates

\begin{abstract}
Ceramic-metal composites with novel performance are desirable materials; however, differences in their properties result in difficulties in joining. In this study, the joining of metal to ceramic is investigated. We recently succeeded in causing super-spread wetting on the surface fine crevice structures of metal surfaces produced by both laser irradiation and reduction-sintering of oxide powders. In this work, joining copper onto an $\mathrm{Al}_{2} \mathrm{O}_{3}$ plate was achieved by taking advantage of super-spread wetting. $\mathrm{Fe}_{2} \mathrm{O}_{3}$ powder was first sintered under reducing conditions to produce a microstructure which can cause super-spread wetting of liquid metal on an $\mathrm{Al}_{2} \mathrm{O}_{3}$ plate. A powder-based surface fine crevice structure of metallic iron with high porosity was well-formed due to the bonding of the reduced metallic iron particles. This structure was joined on an $\mathrm{Al}_{2} \mathrm{O}_{3}$ plate with no cracking by the formation of an $\mathrm{FeAl}_{2} \mathrm{O}_{4}$ layer buffering the mismatch gap between the thermal expansion coefficients of iron and $\mathrm{Al}_{2} \mathrm{O}_{3}$. We successfully achieved metalizing of the $\mathrm{Al}_{2} \mathrm{O}_{3}$ surface with copper without interfacial cracks using super-spread wetting of liquid copper through the sintered metallic iron layer on the $\mathrm{Al}_{2} \mathrm{O}_{3}$ plate. Then, laser irradiation was conducted on the surface of the copper-metalized $\mathrm{Al}_{2} \mathrm{O}_{3}$ plate. A laser-irradiated surface fine crevice structure was successfully created on the copper-metalized $\mathrm{Al}_{2} \mathrm{O}_{3}$ plate. Moreover, it was confirmed that the super-spread wetting of liquid tin occurred on the laser-irradiated surface fine crevice structure, finally accomplishing the joining of a copper block and the copper-metalized $\mathrm{Al}_{2} \mathrm{O}_{3}$.
\end{abstract}

Keywords: metal-ceramic joining; super-spread wetting; wetting; surface fine crevice structure; laser irradiation; reduction sintering

\section{Introduction}

Ceramic-metal joining is required in a wide range of engineering applications on account of the beneficial properties of this material combination. Brazing, a bonding technique in which a continuous interface between two solid materials is formed via the spreading of a filler liquid metal into a joint, has been widely employed for ceramic-metal joining [1-3]. However, two major problems exist for the joining of a ceramic and a metal by brazing: namely, the poor wettability of ceramics by most metals and the large differences in physical properties between ceramics and metals [4-7]. Because a molten metal generally cannot wet ceramic materials, ceramic-metal joining by brazing starts with metallization of the ceramic to create a more wettable surface $[4,5]$. The thermal expansion coefficient of a ceramic is generally much lower than that of a metal. When a material is cooled from a metalizing or brazing process, the thermal expansion mismatch generates thermal stress at the ceramic-metal interface, eventually resulting in cracks [6,7]. Therefore, achieving a successful joint in a ceramic-metal join by brazing is still a challenge. 
Alumina $\left(\mathrm{Al}_{2} \mathrm{O}_{3}\right)$ is a popular ceramic material because of its various properties, including high strength, high resistance to wear and corrosion, and high electrical insulation [8-10], so joining alumina ceramic to a metal has become an important topic. A combination of metal- $\mathrm{Al}_{2} \mathrm{O}_{3}$, for example, $\mathrm{Cu}-\mathrm{Al}_{2} \mathrm{O}_{3}$ joining, may provide not only the abovementioned characteristics of $\mathrm{Al}_{2} \mathrm{O}_{3}$, but also the advantages of copper, which include high conductivity and machinability. It has been reported that the molten copper-solid $\mathrm{Al}_{2} \mathrm{O}_{3}$ couple shows contact angles of $158^{\circ}-170^{\circ}$ at $1100-1300^{\circ} \mathrm{C}$ under oxygen-free conditions [11,12], which indicates that these materials are non-wetting. Likewise, most metals exhibit poor wetting ability for ceramics; such low wettability of $\mathrm{Al}_{2} \mathrm{O}_{3}$ by liquid copper is one of the major difficulties in achieving a good $\mathrm{Cu}-\mathrm{Al}_{2} \mathrm{O}_{3}$ join.

Our research group discovered a phenomenon known as "super-spread wetting", in which a liquid metal penetrates into the fine surface structure of a solid metal that has high porosity, similar to that of a sponge structure, by capillary action, and completely spreads on that surface [13-21]. Our research group [13-15] originally found that super-spread wetting occurs on the surface fine porous structure that is produced by atmospheric oxidation-reduction treatment of a metal surface. In further studies, we found two kinds of surface fine crevice structures that can promote region-selective super-spread wetting of liquid metals: namely, (1) a laser-irradiated surface fine crevice structure, created by laser irradiation [16-20] and (2) a powder-based surface fine crevice structure, created by reduction sintering of an oxide powder [21] on copper and iron surfaces. Super-spread wetting of these two surface fine crevice structures showed that similar and dissimilar metal-to-metal joining, such as $\mathrm{Cu}$-Cu $[16,17,21]$ and $\mathrm{Cu}-\mathrm{Fe}[20]$ joining, can be achieved. Super-spread wetting is believed to be applicable to solving limitations of ceramic-to-metal joining caused by low wettability.

In this study, a ceramic-metal joining technique using super-spread wetting is proposed to address the challenge of joining an $\mathrm{Al}_{2} \mathrm{O}_{3}$ ceramic plate and copper block as a representative ceramic-metal combination. The technique comprises two steps: metallization of the ceramic surface and joining between the metalized ceramic and metal part. In the metallization step, we first carried out sintering of $\mathrm{Fe}_{2} \mathrm{O}_{3}$ powder under an atmospheric-reducing condition in which $\mathrm{Fe}_{2} \mathrm{O}_{3}$ is reduced to $\mathrm{FeO}$ and metallic Fe. This provides the method for producing a powder-based surface fine crevice structure that can cause super-spread wetting on the surface of the $\mathrm{Al}_{2} \mathrm{O}_{3}$ plate. We then metalized the $\mathrm{Al}_{2} \mathrm{O}_{3}$ plate with copper using super-spread wetting of liquid copper on the surface structure of the sintered metallic iron layer formed on the surface of the $\mathrm{Al}_{2} \mathrm{O}_{3}$ plate. In a joining step, laser irradiation was used to form a surface fine crevice structure on the metalized $\mathrm{Al}_{2} \mathrm{O}_{3}$ plate. Finally, metal copper-to-metalized $\mathrm{Al}_{2} \mathrm{O}_{3}$ plate joining by super-spread wetting on the surface fine crevice structure was attempted.

\section{Experimental Method}

\subsection{Metallizing}

Using the characteristics of super-spread wetting, we first investigated copper metalizing on an $\mathrm{Al}_{2} \mathrm{O}_{3}$ plate by forming a metallic iron surface fine crevice structure and penetrating copper into that structure. Figure 1 a shows a schematic diagram of the experimental procedure. A $15 \mathrm{~mm} \times 15 \mathrm{~mm} \times 2.5 \mathrm{~mm}$ plate of $\mathrm{Al}_{2} \mathrm{O}_{3}$ (99.5\% purity), $\mathrm{Fe}_{2} \mathrm{O}_{3}$ powders $(<3 \mu \mathrm{m}, 95 \%$ purity), and a copper block ( $99.99 \%$ purity) were used. A slurry was first prepared by mixing $2.2 \mathrm{~g}$ of $\mathrm{Fe}_{2} \mathrm{O}_{3}$ powder with $4 \mathrm{~mL}$ of ethanol. The $\mathrm{Fe}_{2} \mathrm{O}_{3}$ slurry was applied onto the $\mathrm{Al}_{2} \mathrm{O}_{3}$ plate and the ethanol evaporated. The sample was heated to sinter the $\mathrm{Fe}_{2} \mathrm{O}_{3}$ powders plated on the surface of the $\mathrm{Al}_{2} \mathrm{O}_{3}$ plate. The temperature profile for sintering is shown in Figure $1 \mathrm{~b}$. The atmosphere in the furnace was maintained during heating using an $\operatorname{Ar}(99.99 \%$ purity) gas flow rate of $6 \mathrm{~mL} / \mathrm{min}$. When the temperature reached $1373 \mathrm{~K}$, a mixture of $\mathrm{CO}_{2}$ gas $\left(99.99 \%\right.$ purity, $60 \mathrm{~mL} / \mathrm{min}$ flow rate) and $\mathrm{H}_{2}$ gas $(99.995 \%$ purity, $15 \mathrm{~mL} / \mathrm{min}$ flow rate) was introduced into the furnace and the Ar flow was stopped. The atmosphere in the furnace was maintained at an oxygen partial pressure about $10^{-12} \mathrm{~atm}$ during the sintering process to reduce $\mathrm{Fe}_{2} \mathrm{O}_{3}$ to $\mathrm{FeO}$ and metallic Fe. After this gas-exchange process, the temperature was kept constant for $1 \mathrm{~h}$ to complete the sintering. The temperature was then decreased to $298 \mathrm{~K}$ in a mixed 
gas atmosphere of Ar gas $(60 \mathrm{~mL} / \mathrm{min})$ and $\mathrm{H}_{2}$ gas $(15 \mathrm{~mL} / \mathrm{min})$. The obtained sintered sample was subsequently subjected to metalizing with copper using super-spread wetting. A mass of $0.2 \mathrm{~g} \mathrm{Cu}$ was placed on the sintered metallic iron layer on the $\mathrm{Al}_{2} \mathrm{O}_{3}$ plate, as shown in Figure 1a. The melting point of copper is $1356 \mathrm{~K}$ [22], so the sample was heated to $1373 \mathrm{~K}$ to completely melt the copper using the heating process shown in Figure $1 \mathrm{~b}$. A reducing atmosphere with a mixed gas of Ar gas $(60 \mathrm{~mL} / \mathrm{min})$ and $\mathrm{H}_{2}$ gas $(15 \mathrm{~mL} / \mathrm{min})$ was employed during the heating step of metalizing to prevent oxidation of the sample.

(a)

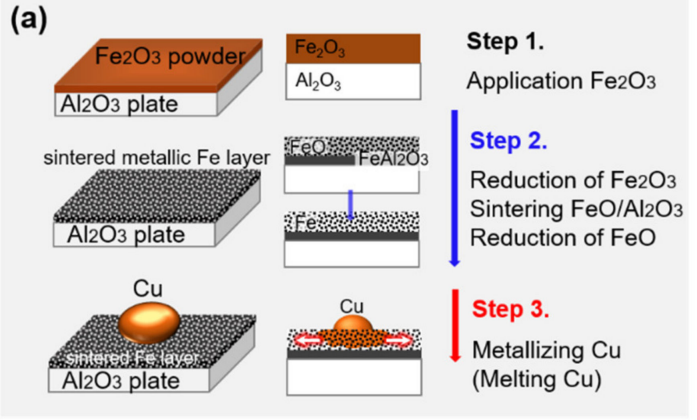

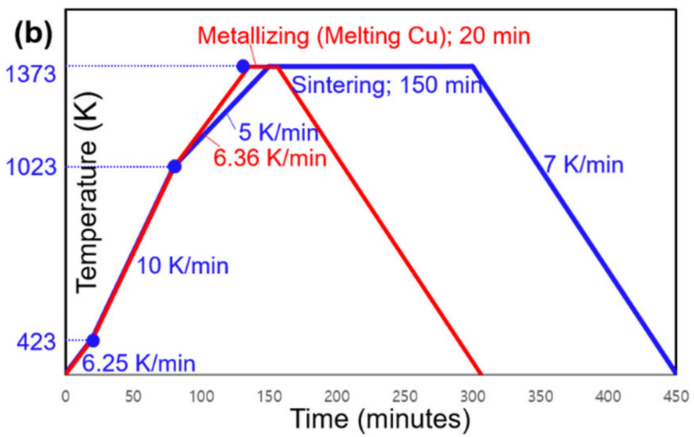

Figure 1. (a) Schematic diagram of experimental procedure; (b) Heating profiles used in Step 2 (blue line) of simultaneous reduction and sintering of applied $\mathrm{Fe}_{2} \mathrm{O}_{3}$ and in Step 3 (red line) of metalizing copper.

\subsection{Joining}

We attempted to join a copper block to the copper-metalized $\mathrm{Al}_{2} \mathrm{O}_{3}$ plate using super-spread wetting into a laser-irradiated surface fine crevice structure. Figure 2 illustrates the sample preparation and setting for the joining experiment. A $5 \mathrm{~mm} \times 5 \mathrm{~mm} \times 2 \mathrm{~mm}$ copper block was used as the metal object to be joined to the metalized $\mathrm{Al}_{2} \mathrm{O}_{3}$ plate and tin was used as liquid material to be penetrated between two materials to join them. They were cleaned in an ethanol bath with ultrasonic treatment. Laser irradiation was conducted to produce a surface fine crevice structure in a $5 \mathrm{~mm} \times 7 \mathrm{~mm}$ region on the copper-metalized surface of the $\mathrm{Al}_{2} \mathrm{O}_{3}$ plate and the entire surface of one side of the copper block. A Q-switched Nd:YAG laser (ML-7062A, Miyachi Corporation, Tokyo, Japan) with a wavelength of $1064 \mathrm{~nm}$ was used for the laser-irradiation process. Each surface to be irradiated was positioned at a distance of $110 \mathrm{~mm}$ from the scanning lens, so that the laser beam focus was adjusted to a spot diameter of $0.1 \mathrm{~mm}$. The maximum output power of the laser was $50 \mathrm{~W}$ at a frequency of $6.0 \mathrm{kHz}$. Laser irradiation was carried out at a scanning rate of $10 \mathrm{~mm} / \mathrm{s}$ and a scanning interval of $0.01 \mathrm{~mm}$, using a grid pattern, i.e., scanning in horizontal and vertical directions. Our previous study reported that copper oxides of $\mathrm{CuO}$ and $\mathrm{Cu}_{2} \mathrm{O}$ are generated in response to laser treatment [16] under the same conditions as this experiment. Therefore, the copper block and copper-metalized $\mathrm{Al}_{2} \mathrm{O}_{3}$ plate were heated at $773 \mathrm{~K}$ for $1 \mathrm{~h}$ under reducing conditions with a $\mathrm{H}_{2}$ gas flow rate of $20 \mathrm{~mL} / \mathrm{min}$ to reduce these formed oxides. After reduction, the copper block was placed on the copper-metalized $\mathrm{Al}_{2} \mathrm{O}_{3}$ plate, such that the laser-irradiated surfaces were in contact with each other, as illustrated in Figure 2. A piece of tin, which was used as liquid metal to be infiltrated into the joint of the copper block and metalized $\mathrm{Al}_{2} \mathrm{O}_{3}$ plate, was placed on the laser-irradiated region of the underlaid copper-metalized $\mathrm{Al}_{2} \mathrm{O}_{3}$ plate. After transferring this setup into a furnace, residual air was evacuated, a flow of $\mathrm{H}_{2}$ gas was introduced at a flow rate of $20 \mathrm{~mL} / \mathrm{min}$, and the sample was heated to $773 \mathrm{~K}$ at a heating rate of $10 \mathrm{~K} / \mathrm{min}$. Once the temperature reached $773 \mathrm{~K}$, the sample was cooled down to $298 \mathrm{~K}$ at a rate of $10 \mathrm{~K} / \mathrm{min}$.

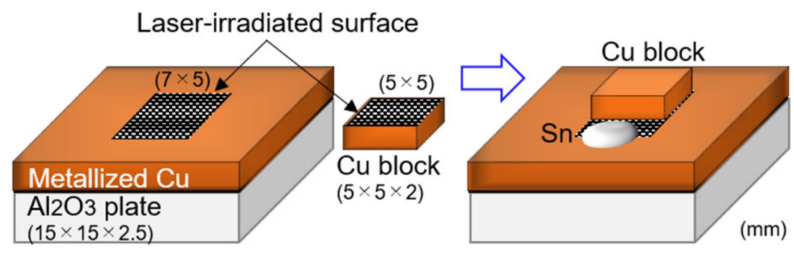

Figure 2. Illustration of the process used for joining experiments. 


\section{Results and Discussion}

3.1. Copper Metallizing of $\mathrm{Al}_{2} \mathrm{O}_{3}$ Plate by Super-Spread Wetting into Powder-Based Metallic Iron Surface Fine Crevice Structure

Figure 3 shows scanning electron microscope observation of a cross-section of the $\mathrm{Al}_{2} \mathrm{O}_{3}$ plate after simultaneous sintering of the $\mathrm{Fe}_{2} \mathrm{O}_{3}$ powder and its reduction to metallic iron on its surface. Using energy-dispersive spectroscopy (EDS, JSM-6500F, JEOL, Tokyo, Japan), the compositions of the dark-gray-colored lower and white upper parts were identified as $\mathrm{Al}_{2} \mathrm{O}_{3}$ and metallic iron, respectively. Metallic iron particles bonded well with each other on the sintered layer, giving a thickness of around $140 \mu \mathrm{m}$. It was assumed that the thickness of the sintered metallic iron layer, i.e., the powder-based surface fine crevice structure of metallic iron, could be controlled by adjusting the amount of $\mathrm{Fe}_{2} \mathrm{O}_{3}$ slurry. Many pores formed between the bonded iron particles, which were irregularly connected and scattered on the sintered layer. In contrast, from the magnified image (Figure 3b), another very thin layer with thickness of around $3 \mu \mathrm{m}$ was observed between the powder-based surface fine crevice structure of metallic iron and the $\mathrm{Al}_{2} \mathrm{O}_{3}$ plate. This was identified as $\mathrm{FeAl}_{2} \mathrm{O}_{4}$ by EDS analysis.

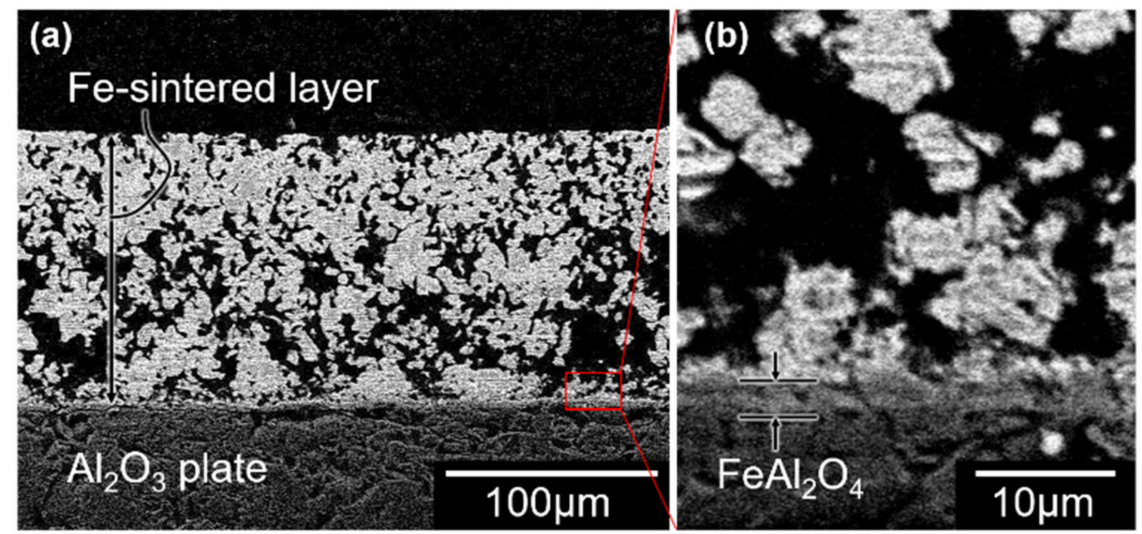

Figure 3. (a) Cross-section of the powder-based surface fine crevice structure of metallic iron created on the $\mathrm{Al}_{2} \mathrm{O}_{3}$ plate by sintering of $\mathrm{Fe}_{2} \mathrm{O}_{3}$ powder under reducing conditions; (b) Magnified image of the region of interface between $\mathrm{Fe}-$ sintered layer and $\mathrm{Al}_{2} \mathrm{O}_{3}$ plate.

It is supposed that each layer was produced by the following mechanisms. During the heating process at $1373 \mathrm{~K}$, the oxygen partial pressure was maintained at about $10^{-12} \mathrm{~atm}$. On the basis of the Fe-O phase diagram [23] given in Figure 4, $\mathrm{FeO}$ is presumed to be present at the high temperature. On the basis of the FeO- $\mathrm{Al}_{2} \mathrm{O}_{3}$ phase diagram [24] given in Figure 5, we expect that the $\mathrm{FeAl}_{2} \mathrm{O}_{4}$ phase appears at the $\mathrm{FeO}-\mathrm{Al}_{2} \mathrm{O}_{3}$ interface at high temperature. Therefore, it is reasonable to assume that $\mathrm{Fe}_{2} \mathrm{O}_{3}$ was first reduced to $\mathrm{FeO}$ at around $1373 \mathrm{~K}$, so that $\mathrm{FeO}$ reacted with $\mathrm{Al}_{2} \mathrm{O}_{3}$ to form $\mathrm{FeAl}_{2} \mathrm{O}_{4}$ at their interface. The $\mathrm{CO}_{2}-\mathrm{H}_{2}$ mixed gas was changed to an $\mathrm{Ar}-\mathrm{H}_{2}$ mixture when switching from holding to cooling, so that the oxygen partial pressure decreased during cooling. Therefore, the remaining FeO that did not react with $\mathrm{Al}_{2} \mathrm{O}_{3}$ was reduced to metallic iron during cooling in this atmosphere of decreased oxygen partial pressure. The suggested reactions can be described as follows:

$$
\begin{gathered}
\mathrm{Fe}_{2} \mathrm{O}_{3} \rightarrow 2 \mathrm{FeO}+\frac{1}{2} \times \mathrm{O}_{2} \\
\mathrm{FeO}+\mathrm{Al}_{2} \mathrm{O}_{3} \rightarrow \mathrm{FeAl}_{2} \mathrm{O}_{4} \\
\mathrm{FeO} \text { (remaining) } \rightarrow \mathrm{Fe}+\frac{1}{2} \times \mathrm{O}_{2}
\end{gathered}
$$

These interactions eventually led to bonding between the $\mathrm{Al}_{2} \mathrm{O}_{3}$ plate and the powder-based surface fine crevice structure of the metallic iron. No cracking was observed at the $\mathrm{Al}_{2} \mathrm{O}_{3}-\mathrm{FeAl}_{2} \mathrm{O}_{4}-\mathrm{Fe}$ interfaces. Fujimura et al. [25] reported that the thermal expansion coefficient of $\mathrm{FeAl}_{2} \mathrm{O}_{4}$ is larger 
than that of $\mathrm{Al}_{2} \mathrm{O}_{3}$, but smaller than that of iron. Therefore, it was considered that $\mathrm{FeAl}_{2} \mathrm{O}_{4}$ acts as a buffer layer, which would reduce the mismatch gap between the thermal expansion coefficients of iron and $\mathrm{Al}_{2} \mathrm{O}_{3}$. This system may make a good joint by suppressing crack formation at the interfaces. Consequently, it was confirmed that a powder-based surface fine crevice structure of metallic iron can be created on an $\mathrm{Al}_{2} \mathrm{O}_{3}$ plate via sintering $\mathrm{Fe}_{2} \mathrm{O}_{3}$ under reducing conditions.

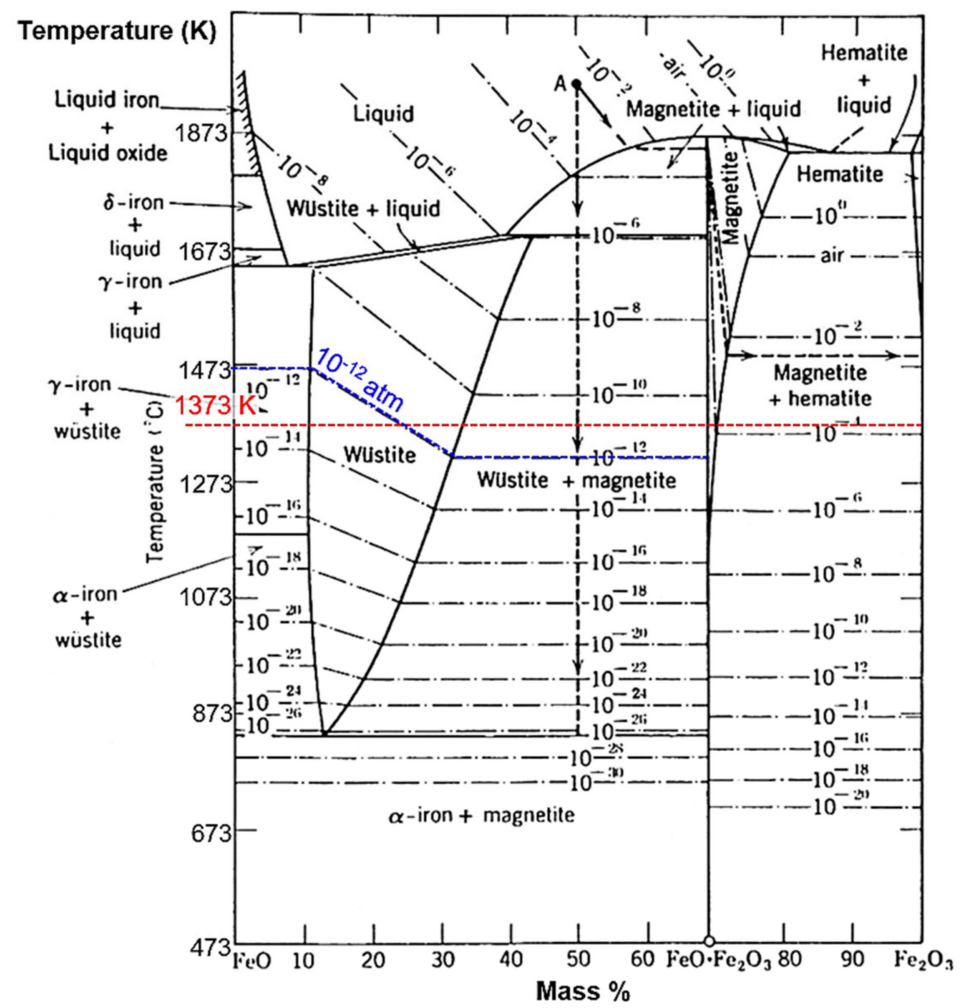

Figure 4. Phase diagram of $\mathrm{FeO}-\mathrm{Fe}_{2} \mathrm{O}_{3}$ system with oxygen pressure isobars. Reproduced with permission from [23], Elsevier, 1999.

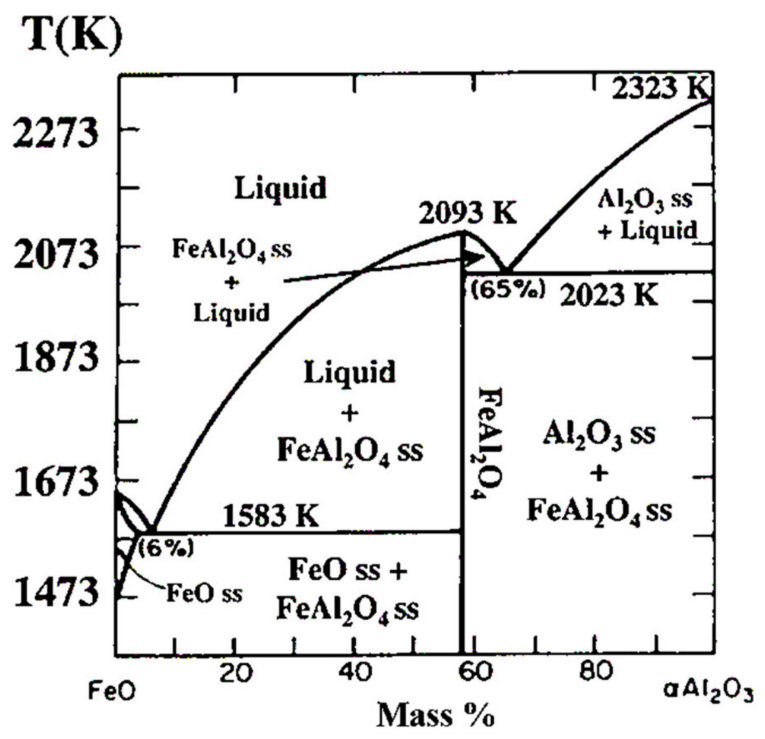

Figure 5. Phase diagram of FeO-Al2O3 system. Reproduced with permission from [24], Royal Society of Chemistry, 2002.

Figure 6a shows the appearance of the sample after copper metalizing. The initial position of the copper piece was in the central part of the sintered metallic iron layer on the $\mathrm{Al}_{2} \mathrm{O}_{3}$ plate. However, 
the copper spread by wetting through the powder-based surface fine crevice structure of metallic iron, therefore, the entire region of the sintered metallic iron layer on the $\mathrm{Al}_{2} \mathrm{O}_{3}$ plate was covered with copper. From the cross-section of the sample, shown in Figure 6b, it was observed that the copper completely infiltrated the powder-based surface fine crevice structure of metallic iron. This indicates that super-spread wetting of copper occurred through this structure. However, as can be predicted from the Fe-Cu phase diagram [26], the metallic iron structure slightly dissolved into the copper. In addition, it was observed that no obvious voids or cracks formed on any interfaces of $\mathrm{Cu}-\mathrm{Fe}, \mathrm{Fe}_{-} \mathrm{Fe} \mathrm{Al}_{2} \mathrm{O}_{4}$, or $\mathrm{FeAl}_{2} \mathrm{O}_{4}-\mathrm{Al}_{2} \mathrm{O}_{3}$, resulting in good metalizing of copper onto the $\mathrm{Al}_{2} \mathrm{O}_{3}$ plate. These results indicated that the metallization of the $\mathrm{Al}_{2} \mathrm{O}_{3}$ plate with copper was achieved by super-spread wetting of liquid copper via the powder-based surface fine crevice structure of metallic iron produced on the $\mathrm{Al}_{2} \mathrm{O}_{3}$.
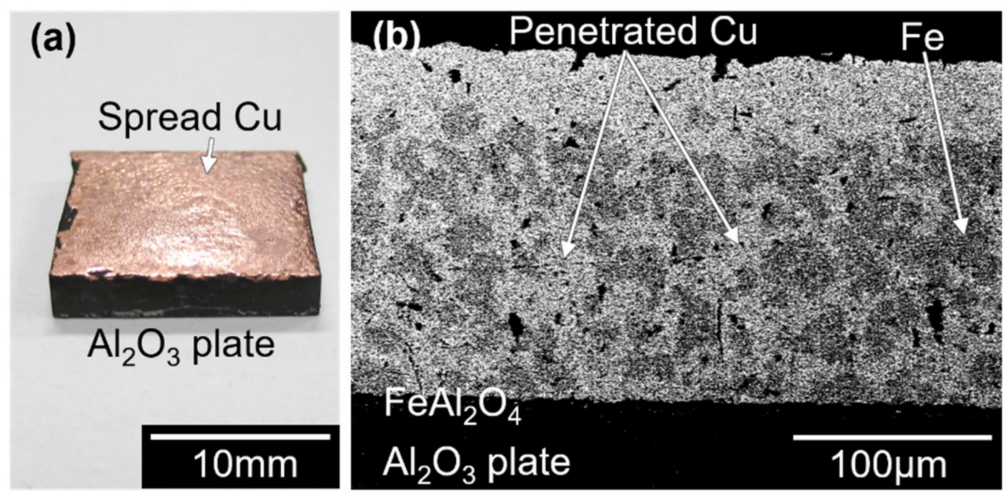

Figure 6. (a) Appearance and (b) cross-section of sample after copper metalizing.

\subsection{Joining of Copper Block onto $\mathrm{Al}_{2} \mathrm{O}_{3}$ Plate with Surface Fine Crevice Structure Created by Laser Irradiation}

Figure 7 shows the surface and cross-section of the copper (iron contained or dissolved)-metallized $\mathrm{Al}_{2} \mathrm{O}_{3}$ plate after laser irradiation. The laser-irradiated surface fine crevice structure of metallic copper consisted of many asperities and gaps formed on the surface of the metal layer of copper and iron on the $\mathrm{Al}_{2} \mathrm{O}_{3}$ plate. This structure is similar to the surface fine crevice structure created on a pure copper plate by laser irradiation [16,18]. In addition, as shown in Figure $6 \mathrm{~b}$, the $\mathrm{FeAl}_{2} \mathrm{O}_{4}$ layer remained, even after laser irradiation. This might serve to maintain the bonding of the metal layer of copper and iron and $\mathrm{Al}_{2} \mathrm{O}_{3}$ plate without cracking occurring at their interfaces. The above results confirmed that the laser-irradiated surface fine crevice structure of metallic copper was well produced on the copper-metalized $\mathrm{Al}_{2} \mathrm{O}_{3}$ plate by laser irradiation.
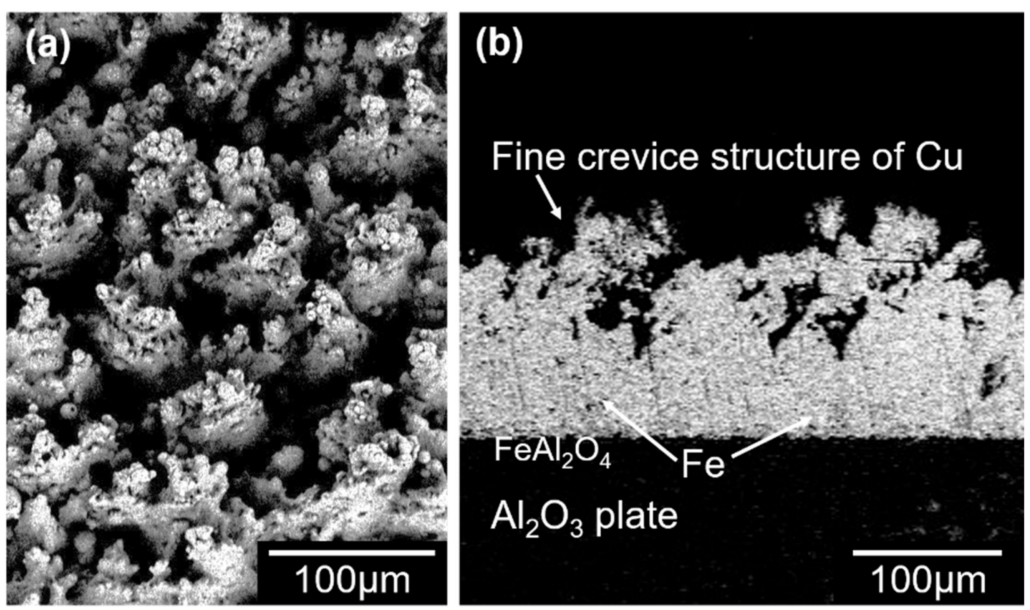

Figure 7. (a) Surface and (b) cross-section of laser-irradiated surface fine crevice structure of metallic copper created on the surface of copper (iron contained or dissolved)-metallized $\mathrm{Al}_{2} \mathrm{O}_{3}$ plate. 
The appearance of the sample after joining is shown in Figure 8a. Tin placed on the laser-irradiated region of the underlaid copper-metalized $\mathrm{Al}_{2} \mathrm{O}_{3}$ plate disappeared by spreading into the joint interface between the upper copper block and the lower $\mathrm{Al}_{2} \mathrm{O}_{3}$ plate. Even when the upper copper block was lifted up, it was well joined with the copper-metalized $\mathrm{Al}_{2} \mathrm{O}_{3}$ plate so the two did not separate from each other.

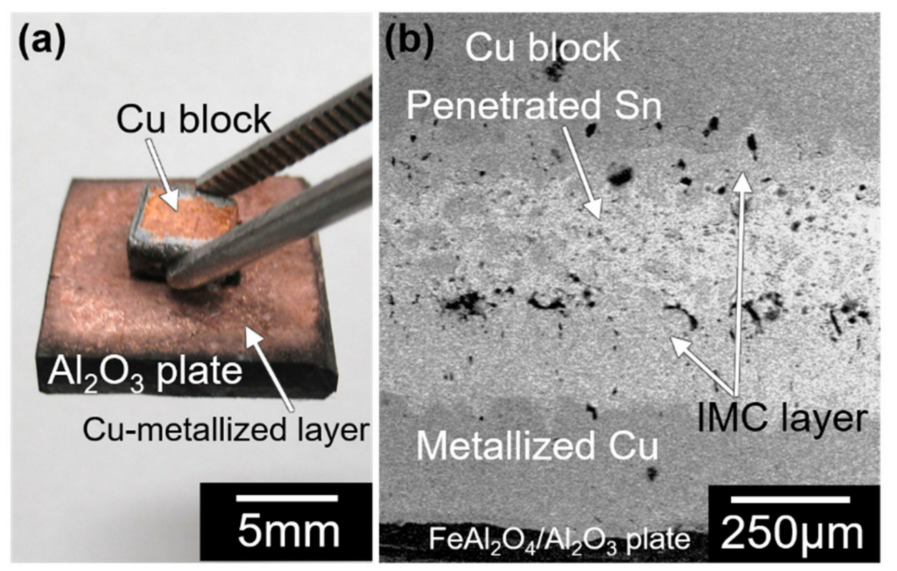

Figure 8. (a) Appearance of sample after joining experiment and (b) cross-section of the junction.

Figure $8 \mathrm{~b}$ shows a cross-section of the junction. All space between the upper copper block and lower copper metalized $\mathrm{Al}_{2} \mathrm{O}_{3}$ plate was completely filled with tin. Moreover, an intermetallic compound (IMC) layer was formed along the laser-irradiated surface fine crevice structure. We conducted composition analysis of some spots of the IMC layer by using EDS to identify the IMCs. The EDS analysis results indicate that the IMC layer formed at $\mathrm{Cu}$ block side was composed of $\mathrm{Cu}_{3} \mathrm{Sn}$ and $\mathrm{Cu}_{6} \mathrm{Sn}_{5}$, while that formed at the metalized $\mathrm{Cu}$ side included $\mathrm{Cu}_{3} \mathrm{Sn}, \mathrm{Cu}_{6} \mathrm{Sn}_{5}$, and FeSn. This means that tin penetrated into the laser-irradiated surface fine crevice structure of both the upper copper block and the lower copper-metalized $\mathrm{Al}_{2} \mathrm{O}_{3}$ plate by super-spread wetting. In addition, it was presumed that both the upper and lower laser-irradiated surfaces changed into the intermetallic compound layer due to wetting by tin. However, some micro-pores were formed at the interface between the IMC layer and tin, as found in Figure 8b. Thermal expansion coefficients of $\mathrm{Cu}_{3} \mathrm{Sn}, \mathrm{Cu}_{6} \mathrm{Sn}_{5}, \mathrm{FeSn}$, and pure Sn are 19, 16.3, 19, and $23.4 \mathrm{ppm} /{ }^{\circ} \mathrm{C}$ [27-29], respectively. The thermal expansion coefficient of Sn was significantly large compared to that of $\mathrm{Cu}_{3} \mathrm{Sn}, \mathrm{Cu}_{6} \mathrm{Sn}_{5}$, and FeSn. Thus, it is supposed that this mismatch of thermal expansion (CTE) between the IMC layer and tin layer caused the formation of voids at the junction. These voids' formation at the joining interface of the joint would significantly degrade the mechanical robustness of the inter-connection [30]. It is considered that this problem can be solved by decreasing the mismatch of CTE on the joining interface, i.e., by determining the appropriate solder materials for application. Therefore, it is proposed that the joining of a copper block onto an $\mathrm{Al}_{2} \mathrm{O}_{3}$ plate was successfully accomplished by super-spread wetting of tin on the laser-irradiated surface fine crevice structure of metallic copper. Our research groups $[16,18]$ have found that the surface fine crevice structures enable super-spread wetting of liquid Bi on solid $\mathrm{Cu}$ and also wetting of liquid Bi, Sn, and In on solid Fe, as well as the wetting of liquid $\mathrm{Cu}$ /solid Fe and liquid $\mathrm{Sn} /$ solid Fe. This means that the super-spread wetting of liquid metal on the surface fine crevice structure derived from the capillary action can allow one to metalize ceramic or join ceramic to metal with various ceramic-metal combinations. Consequently, we believe that this joining technique will help advance the joining of ceramic-metal systems with difficulty related to the lack of wettability.

\section{Conclusions}

In this study, we proposed a method for joining a metal block to a ceramic plate using super-spread wetting. Metallization of $\mathrm{Al}_{2} \mathrm{O}_{3}$ with copper was first tried using super-spread wetting. $\mathrm{An} \mathrm{Fe}_{2} \mathrm{O}_{3}$ powder sintered under reducing conditions was used to form a powder-based surface fine crevice 
structure of metallic iron that could lead to super-spread wetting of a liquid metal on an $\mathrm{Al}_{2} \mathrm{O}_{3}$ plate. We investigated the wetting of liquid copper on the powder-based surface fine crevice structure of metallic iron to metalize the surface of the $\mathrm{Al}_{2} \mathrm{O}_{3}$ plate. Formation of a laser-irradiated surface fine crevice structure of metallic copper on the copper-metalized $\mathrm{Al}_{2} \mathrm{O}_{3}$ plate and joining of a copper block to a copper-metalized $\mathrm{Al}_{2} \mathrm{O}_{3}$ plate using super-spread wetting into their surface fine crevice structures were attempted. The experimental results led to the following findings:

(1) A powder-based surface fine crevice structure of metallic iron with a high porosity was created by sintering of $\mathrm{Fe}_{2} \mathrm{O}_{3}$ powder under reducing conditions. The sintered metallic iron layer bonded well to the surface of an $\mathrm{Al}_{2} \mathrm{O}_{3}$ plate due to the $\mathrm{FeAl}_{2} \mathrm{O}_{4}$ layer formed at the interface of the sintered metallic iron layer and $\mathrm{Al}_{2} \mathrm{O}_{3}$ plate during the heating process of the reduction of $\mathrm{Fe}_{2} \mathrm{O}_{3}$ to $\mathrm{FeO}$.

(2) Super-spread wetting of liquid copper occurred on the powder-based surface fine crevice structure of metallic iron, which achieved copper metalizing of the $\mathrm{Al}_{2} \mathrm{O}_{3}$ plate surface.

(3) A laser-irradiated surface fine crevice structure was produced on the copper-metalized $\mathrm{Al}_{2} \mathrm{O}_{3}$ plate by laser irradiation. Joining of a copper block onto the copper-metalized $\mathrm{Al}_{2} \mathrm{O}_{3}$ plate was achieved using super-spread wetting of liquid tin through the structure.

Author Contributions: Methodology, M.Y. and M.N.; validation, M.Y.; investigation, J.Y. and M.Y.; writing—original draft preparation, J.Y.; writing - review and editing, P.N. and M.N.; supervision, T.T.; funding acquisition, J.Y., M.N and T.T. All authors have read and agreed to the published version of the manuscript.

Funding: This research was funded by Research Fellow of Japan Society for the Promotion of Science (Grant number: 20J10009).

Acknowledgments: The authors would like to thank Nobuyuki Takahira for his great support and fruitful discussions in the experiment on metallization.

Conflicts of Interest: The authors declare no conflict of interest.

\section{References}

1. Li, C.; Huang, C.; Chen, L.; Si, X.; Chen, Z.; Qi, J.; Huang, Y.; Feng, J.; Cao, J. Microstructure and mechanical properties of the $\mathrm{SiC} / \mathrm{Nb}$ joint brazed using $\mathrm{AgCuTi}+\mathrm{B} 4 \mathrm{C}$ composite filler metal. Int. J. Refract. Met. Hard Mater. 2019, 85, 105049. [CrossRef]

2. Way, M.; Willingham, J.; Goodall, R. Brazing filler metals. Int. Mater. Rev. 2020, 65, 257-285. [CrossRef]

3. Hu, S.P.; Hu, T.Y.; Lei, Y.Z.; Song, X.G.; Liu, D.; Cao, J.; Tang, D.Y. Microstructural evolution and mechanical properties of vacuum brazed Ti2AlNb alloy and Ti60 alloy with Cu75Pt filler metal. Vacuum 2018, 152, 340-346. [CrossRef]

4. Mishra, S.; Sharma, A.; Jung, D.H.; Jung, J.P. Recent Advances in Active Metal Brazing of Ceramics and Process. Met. Mater. Int. 2020, 26, 1087-1098. [CrossRef]

5. Santuan, Z.; Xiangzhao, Z.; Guiwu, L.; Fabrizio, V.; MariaLuigia, M.; Guanjun, Q.; Alberto, P. Surface Metallization of SiC Ceramic by Mo-Ni-Si Coatings for Improving Its Wettability by Molten Ag. Rare Met. Mater. Eng. 2018, 47, 759-765. [CrossRef]

6. Shen, Y.-L. Thermal expansion of metal-ceramic composites: A three-dimensional analysis. Mater. Sci. Eng. A 1998, 252, 269-275. [CrossRef]

7. Kovalev, S.P.; Miranzo, P.; Osendi, M.I. Finite element simulation of thermal residual stresses in joining ceramics with thin metal interlayers. J. Am. Ceram. Soc. 1998, 81, 2342-2348. [CrossRef]

8. Li, J.Q.; Xiao, P. Joining alumina using an alumina/metal composite. J. Eur. Ceram. Soc. 2002, 22, 1225-1233. [CrossRef]

9. Asthana, R.; Singh, M. Joining of partially sintered alumina to alumina, titanium, Hastealloy and C-SiC composite using Ag-Cu brazes. J. Eur. Ceram. Soc. 2008, 28, 617-631. [CrossRef]

10. Shin, J.; Sharma, A.; Jung, D.H.; Jung, J.P. Effect of Sn content on filler and bonding characteristics of active metal brazed $\mathrm{Cu} / \mathrm{Al}_{2} \mathrm{O}_{3}$ joint. J. Korean Inst. Met. Mater. 2018, 56, 366-374. [CrossRef]

11. Ghetta, V.; Chatain, D. Morphologies Adopted by Al2O3 Single-Crystal Surfaces in Contact with Cu Droplets. J. Am. Ceram. Soc. 2002, 85, 961-964. [CrossRef] 
12. Shen, P.; Fujii, H.; Matsumoto, T.; Nogi, K. Influence of substrate crystallographic orientation on the wettability and adhesion of $\alpha-\mathrm{Al}_{2} \mathrm{O}_{3}$ single crystals by liquid $\mathrm{Al}$ and Cu. J. Mater. Sci. 2005, 40, 2329-2333. [CrossRef]

13. Takahira, N.; Tanaka, T.; Hara, S.; Lee, J. Unusual Wetting of Liquid Metals on Iron Substrate with Oxidized Surface in Reduced Atmosphere. Mater. Trans. 2005, 46, 3008-3014. [CrossRef]

14. Takahira, N.; Yoshikawa, T.; Tanaka, T.; Holappa, L. Wettability of Liquid In and Bi on Flat and Porous Solid Iron Substrate. Mater. Trans. 2007, 48, 2708-2711. [CrossRef]

15. Takahira, N.; Yoshikawa, T.; Tanaka, T.; Holappa, L. Unusual Wetting of Liquid Bismuth on a Surface-Porous Copper Substrate Fabricated by Oxidation-Reduction Process. Mater. Trans. 2007, 48, 3126-3131. [CrossRef]

16. Fukuda, A.; Matsukawa, H.; Goto, H.; Suzuki, M.; Nakamoto, M.; Matsumoto, R.; Utsunomiya, H.; Tanaka, T. Metal-Metal Joining by Unusual Wetting on Surface Fine Crevice Structure Formed by Laser Treatment. Mater. Trans. 2015, 56, 1852-1856. [CrossRef]

17. Nakamoto, M.; Fukuda, A.; Pinkham, J.; Vilakazi, S.; Goto, H.; Matsumoto, R.; Utsunomiya, H.; Tanaka, T. Joining of Copper Plates by Unusual Wetting with Liquid Tin and Tin-Lead Solder on "Surface Fine Crevice Structure". Mater. Trans. 2016, 57, 973-977. [CrossRef]

18. Fukuda, A.; Satake, Y.; Goto, H.; Suzuki, M.; Nakamoto, M.; Matsumoto, R.; Utsunomiya, H.; Tanaka, T. Wettability of Liquid Bi, In and Sn on Surface Fine Crevice Sructure of Laser-Irradiated Solid Iron Substrate. J. Smart Process. 2016, 5, 153-158. [CrossRef]

19. Siboniso, V.; Yeon, J.; Grozescu, C.; Goto, H.; Nakamoto, M.; Matsumoto, R.; Utsunomiya, H.; Tanaka, T. Mechanism of the Unusual Wetting of a Surface Fine Crevice Structure Created by Laser Irradiation. Mater. Trans. 2017, 58, 1227-1230. [CrossRef]

20. Yeon, J.; Kageyama, T.; Yamada, R.; Ni, P.; Nakamoto, M.; Tanaka, T. Dissimilar Metal Joining of Cu and Fe Using Super-Spread Wetting into Surface Fine Crevice Structures. Mater. Trans. 2020, MT-M2020120. [CrossRef]

21. Yeon, J.; Ishida, Y.; Nakamoto, M.; Tanaka, T. Joining of Metals by Super-Spread Wetting on Surface Fine Crevice Structure Created by Reduction-Sintering Copper Oxide Powder. Mater. Trans. 2018, 59, 1192-1197. [CrossRef]

22. Iida, T.; Guthrie, R.I.L. The Thermophysical Properties of Metallic Liquids. Volume 1, Fundamentals, 1st ed.; Oxford University Press: Oxford, UK, 2015; ISBN 9780198729839.

23. Mei, J.; Halldearn, R.D.; Xiao, P. Mechanisms of the aluminium-iron oxide thermite reaction. Scr. Mater. 1999, 41, 541-548. [CrossRef]

24. Maitre, A.; Denoirjean, A.; Fauchais, P.; Lefort, P. Plasma-jet coating of preoxidized XC38 steel: Influence of the nature of the oxide layer. Phys. Chem. Chem. Phys. 2002, 4, 3887-3893. [CrossRef]

25. Fujimura, T.; Tanaka, S.-I. In-situ high temperature X-ray diffraction study of $\mathrm{Fe} / \mathrm{Al}_{2} \mathrm{O}_{3}$ interface reactions. J. Mater. Sci. 1999, 34, 425-429. [CrossRef]

26. Lukyanov, A.; Churakova, A.; Filatov, A.; Levin, E.; Valiev, R.; Gunderov, D.; Antipov, E. Microstructure refinement in Cu-Fe alloy using high pressure torsion. IOP Conf. Ser. Mater. Sci. Eng. 2014, 63. [CrossRef]

27. Fields, R.J.; Low, S.R.; Lucey, G.K. Physical and Mechanical Properties of intermetallic compounds Commonly Found in Solder Joints. In Metal Science of Joining. In Proceedings of the TMS Symposium, Cincinnati, OH, USA, 20-24 October 1991.

28. Sales, B.C.; Yan, J.; Meier, W.R.; Christianson, A.D.; Okamoto, S.; McGuire, M.A. Electronic, magnetic, and thermodynamic properties of the kagome layer compound FeSn. Phys. Rev. Mater. 2019, 3, 1-9. [CrossRef]

29. Snipes, E.K.; Flowers, G.T.; Bozack, M.J. Influence of Systematic Coefficient of Thermal Expansion (CTE) Variations on Sn Whiskering. In Proceedings of the 2016 IEEE 62nd Holm Conference on Electrical Contacts (Holm), Clearwater Beach, FL, USA, 9-12 October 2016; pp. 205-208.

30. Yunus, M.; Srihari, K.; Pitarresi, J.M.; Primavera, A. Effect of voids on the reliability of BGA/CSP solder joints. Microelectron. Reliab. 2003, 43, 2077-2086. [CrossRef]

Publisher's Note: MDPI stays neutral with regard to jurisdictional claims in published maps and institutional affiliations. 